\title{
Caring for caregivers: encouraging intervention activities as a learning strategy in medical internship
}

\section{Cuidando de quem cuida: projeto de intervenção como estratégia de aprendizagem no internato em medicina}

\author{
Ana Vitória Teixeira de Medeiros Gomes ${ }^{1}$ (D) $\mid$ vitória_medeiros@hotmail.com \\ Erika Denise de Vasconcelos Florentino' (D) erikadenisevasconcelos@gmail.com \\ Myrlla Soares de Oliveira' (D) myrlla.soares@gmail.com \\ Thaiany Rego Silva'1D) rego.thaiany@gmail.com \\ Jucimara Alves de Souza² (D) jucimara_alves@hotmail.com
}

\begin{abstract}
Introduction: This work describes the experience of structuring a therapeutic group with informal caregivers who showed signs of overload and who worked providing care to bedridden people followed through home visits by the health team of the Family Health Strategy (FHS).

Experience Report: The group was structured and developed by two students of the Internship period of the medical course during the rotation in Family and Community Medicine (FCM) together with the second-year resident physician of the Specialization Program in FCM, the preceptor of the Program, and the team nurse at the Josefa de Souza Silva school unit, Pedra Linda neighborhood, in Petrolina, state of Pernambuco, based on the identification of a problem in the community and as part of the intervention project.

Discussion: Seven weekly meetings were held with twelve caregivers, from May to July 2019. Each meeting was divided into welcoming activities, presentation of the day's proposal with the experience of a self-care practice and ended with the suggestion of a home activity, to be developed until the next meeting. For the development of activities, the community approach and resources such as Popular Education and Integrative and Complementary Practices in Health were used.

Conclusion: The reduction of stress and overload on caregivers was observed, from the practice of self-care and the strengthening of support networks in the community. At the same time, the potential of the intervention project was perceived as a learning strategy in the process of medical training in the FHS: the students were able to experience the establishment of the doctor-patient relationship, the use of light technologies for care, the coordination of a therapeutic group, understanding the meaning of equity, integrality and longitudinality in the practice of FCM, recognizing themselves as caregivers and the importance of taking care of themselves to take care of others.
\end{abstract}

Keywords: Caregivers; Primary Health Care; Medical Education; Complementary Therapies; Therapeutic Group.

\section{RESUMO}

Introdução: Este trabalho descreve a experiência de estruturação de um grupo terapêutico com cuidadores informais que apresentavam sinais de sobrecarga e que atuavam na prestação de cuidados a pessoas acamadas acompanhadas em visita domiciliar pela equipe de saúde da Estratégia de Saúde da Família (ESF).

Relato de Experiência: O grupo foi estruturado e desenvolvido por duas alunas do período de Internato do curso de Medicina no rodízio de Medicina de Família e Comunidade (MFC) junto a médica residente do segundo ano do Programa de Especialização em MFC, a preceptora do Programa e a enfermeira da equipe na unidade escola Josefa de Souza Silva, bairro Pedra Linda, em Petrolina-Pernambuco, a partir da identificação de um problema na comunidade e como parte do projeto de intervenção.

Discussão: Foram realizados sete encontros semanais com doze cuidadores, no período de maio a julho do ano de 2019. Cada encontro foi dividido em acolhida, apresentação da proposta do dia com a vivência de uma prática de autocuidado e finalizado com a sugestão de uma atividade para casa, a ser desenvolvida até o próximo encontro. Para o desenvolvimento das atividades foram utilizadas a abordagem comunitária e recursos como Educação Popular e Práticas Integrativas e Complementares em Saúde.

Conclusão: Foi observada a diminuição do estresse e sobrecarga nos cuidadores, a partir da prática do autocuidado e do fortalecimento das redes de apoio na comunidade. Paralelamente, foi percebida a potencialidade do projeto de intervenção como estratégia de aprendizado no processo de formação médica na ESF: as alunas puderam experimentar o estabelecimento da relação médico-paciente, o uso de tecnologias leves para o cuidado, a coordenação de um grupo terapêutico, compreender o significado de equidade, integralidade e longitudinalidade na prática da MFC, se reconhecerem como cuidadoras e a importância de cuidar de si para cuidar do outro.

Palavras-chave: Cuidadores; Atenção Primária a Saúde; Educação Médica; Terapias Complementares; Grupo Terapêutico.

${ }^{1}$ Universidade Federal do Vale do São Francisco, Petrolina, Pernambuco, Brazil.

2 Universidade Gama Filho, Rio de Janeiro, Rio de Janeiro, Brazil.

Chief Editor: Rosiane Viana Zuza Diniz.

Associate Editor: Danilo Borges Paulino.

Received on 09/14/2021; Accepted on 11/24/2021.

Evaluated by double blind review process. 


\section{INTRODUCTION}

Caring is love, bonding, zeal, attention dedication, responsibility. Caring is an attitude, it is something that is part of the human being's nature and requires emotional involvement with the other ${ }^{1}$. The action of caring is voluntary and complex, as the caregiver may also have to deal with feelings such as anger, fear, guilt, anguish, stress, sadness and irritation ${ }^{2-4}$. Thus, the presence of such emotions can signal the caregiver's illness $s^{2,5,6}$.

By definition, caregiver overload is the psychological state resulting from the sum of physical exhaustion, emotional pressure, social isolation and economic demands arising from providing assistance to a sick person ${ }^{7,8}$. Factors such as the patient's prolonged illness, the high degree of dependence on assistance, the lack of social support and a period of dedication of more than three years to the sick person are factors that negatively influence the quality of care provided ${ }^{6,9-11}$.

In the context of Primary Health Care (PHC) it is important to identify the presence of stress in the caregiver. The identification of signs of overload can be performed based on the welcoming and attentive listening of the caregiver during the home visit to the sick person ${ }^{6,12}$. Given this situation, it is essential that options are offered to families and caregivers, as the purpose of any action in health is the act of caring. In a context of suffering, the use of light technologies such as meeting, welcoming, establishing bonds, companionship, trust and accountability for the problem to be faced might be enough to reestablish the balance ${ }^{13}$.

Among the interventions to promote care for those who care in $\mathrm{PHC}$ is the therapeutic group ${ }^{14}$. This resource enables the exchange of experiences and the transformation of health practices, based on the meeting between people who share the same anxieties and professionals who work in the health unit and in the Family Health Support Center (NASF, Núcleo de Apoio à Saúde da Família ), in the context of the Brazilian Unified Health System (SUS, Sistema Único de Saúde) ${ }^{14-16}$. Another accessible resource that proposes taking a holistic look at $t^{*}+$ he individual, the community and nature is the use of Integrative and Complementary Practices in Health (PICS, Práticas Integrativas e Complementares em Saúde) ${ }^{17}$. The potential of these practices comes from the integrative logic, which comprises aspects of health, and intertwines them in a multi-, inter- and transdisciplinary manner, embracing academic and community knowledge in the care of people $\mathrm{e}^{18,19}$.

The structuring of a therapeutic group with caregivers overloaded by the demands of care in a health unit in the countryside was motivated by the following factors: a) identification of suffering in caregivers of bedridden people assisted during home visits by the health unit team; b) the great social and economic vulnerability of most residents of the Pedra
Linda neighborhood, on the outskirts of the city of Petrolina, state of Pernambuco, Brazil; c) and the need to structure an intervention project as a learning strategy by two students attending the Internship period at Universidade Federal do Vale do São Francisco (UNIVASF) during the Family and Community Medicine (FCM) rotation in the Family Health Strategy (FHS).

The medical course at UNIVASF is structured in six years, and in the last two years the student experiences the Internship, which is a mandatory internship in health services associated with the university. This structure aims at learning the techniques necessary for medical training, under the supervision of teachers or preceptors in the services. In the first and second year of the Internship, the student will work for periods of eight to ten weeks, in the areas of Internal Medicine, Clinical Surgery, Obstetrics/Gynecology, Pediatrics and $\mathrm{FCM}^{20}$. For the practical assessment of students in the FCM scenario, the development of an intervention project based on the identification of a problem observed in the territory is proposed. This instrument is important because it allows the student to research and critically analyze the reality in which they work, assuming commitments and taking responsibility for people and the community.

The aim of this study was to report the experience of structuring a therapeutic group with informal caregivers who showed signs of overload and by providing care to bedridden people who were followed through home visits by the health team, as an intervention project carried out by students from the Internship period of the medical course during the FCM rotation at the FHS. The group was structured and developed together with the second-year resident physician of the FCM Residency Program, the Program preceptor and the nurse of the team at the Josefa de Souza Silva School Unit, Pedra Linda neighborhood, in the countryside of the state of Pernambuco, Brazil.

\section{EXPERIENCE REPORT}

This is a descriptive study, of an experience report type, carried out from May to July of 2019. The detection of suffering in informal caregivers as a problem was perceived at the students attentive listening during home visits carried out by the ESF team to bedridden patients. The home visit is a teaching-learning tool that is essential to medical training, as it allows experiencing the integrality of care in the individual and collective contexts, in addition to allowing getting close to the determinants of the health-disease process in the family context ${ }^{21}$. This technology allows working on skills and attitudes such as communication, observation, dialogue, oral and written reports, in addition to generating opportunities for the creation of spaces of subjectivity, in which it is possible to identify an essential care network for problem solving and continuity of care ${ }^{22}$. 
The choice of the therapeutic group as a care strategy was possible based on the identification of the situation of suffering in more than one caregiver followed during home visits. To allow the listening and sharing of experiences, it is recommended that each group should have from three to fifteen people and that each meeting should last sixty, ninety or one hundred and twenty minutes, taking place from one to three times a week ${ }^{23}$. The planning of the activities and definition of the objectives to be achieved at each meeting, as well as the listing of materials and budget, were carried out by the students and by the resident physician, considering the ten-week period that corresponds to the duration of the FHS rotation of the students attending the first-year medical internship at UNIVASF.

It was also defined that, by recognizing the importance of bonding and welcoming to strengthen the group, the two students, the resident physician, the Program preceptor and the team nurse would try to be present at all activities and could perform the role of group coordinators. The inclusion criteria comprised: informal caregivers showing signs of overload identified by attentive listening by the resident physician and medical students during the team's home visits to bedridden patients in the territory, whether men or women, aged 18 years and over. Exclusion criteria were not defined, as it was understood that one's mere presence, even in a single meeting, would already mean a success, since the caregiver would be allowing themselves to receive care for a moment of the week and that the absence could occur due to occupations related to caring for themselves or another person.

The therapeutic group was structured based on a community approach and resources such as Popular Education and PICS, with the participation of twelve caregivers who accepted the invitation - in a closed and heterogeneous group. The seven meetings took place in the health unit itself, during the afternoon shift, once a week, lasting from 60 to 90 minutes. Each meeting was divided into: welcoming, listening to the impact of the activity proposed in the previous meeting, the presentation of the day's activity with the experience of a selfcare practice and the conclusion with the suggestion of a task to be developed at home, during the following week, until the subsequent meeting. Each participant's evaluation process was carried out based on attentive listening to the impacts of the activities proposed in the meetings and in the home visits. The structure of each of these activities was described in Table 1.

In the first meeting, each participant was listened to, and answered triggering questions: "Who are you? How do you feel taking care of someone?" and then, using bibliotherapy, the book "A Fada Afilhada" by Márcio Vassalo was read, which playfully highlights the impact of care overload on the caregiver and the importance of self-care. The proposed activities to be

Table 1. Activity planning - group of caregivers, Petrolina, Pernambuco, 2019.

\begin{tabular}{|c|c|c|c|}
\hline & ACTIVITY / OBJECTIVES & RESOURCES & HOME ACTIVITY \\
\hline WEEK 1 MEETING & $\begin{array}{l}\text { Welcoming of caregivers. Answer } \\
\text { the questions: "Who are you?" } \\
\text { and "How do you feel when you } \\
\text { take care of someone?". }\end{array}$ & $\begin{array}{l}\text { Art therapy using children's book } \\
\text { reading (bibliotherapy), use of scents } \\
\text { for the environment and reflexology } \\
\text { (auricular therapy). }\end{array}$ & $\begin{array}{l}\text { Dedicate ten minutes a day to } \\
\text { yourself. }\end{array}$ \\
\hline WEEK 2 MEETING & $\begin{array}{l}\text { Welcoming of caregivers. Answer } \\
\text { the question: "How do you deal } \\
\text { with everyday stresses?" }\end{array}$ & $\begin{array}{l}\text { Art therapy using gardening and } \\
\text { reflexology (auricular therapy). }\end{array}$ & $\begin{array}{l}\text { Cultivate/contemplate } \\
\text { something that allows you to feel } \\
\text { happiness (such as a plant). }\end{array}$ \\
\hline WEEK 3 MEETING & $\begin{array}{l}\text { Welcoming of caregivers. Answer } \\
\text { the question: "who can I ask for } \\
\text { help?". }\end{array}$ & $\begin{array}{l}\text { Construction of the Genogram and } \\
\text { Ecomap and use of scents for the } \\
\text { environment. }\end{array}$ & $\begin{array}{l}\text { Exercising asking for help and } \\
\text { taking a shift off. }\end{array}$ \\
\hline WEEK 4 MEETING & $\begin{array}{l}\text { Welcoming of caregivers. } \\
\text { Recognize the rights of } \\
\text { caregivers. }\end{array}$ & $\begin{array}{l}\text { Art therapy using games and music, } \\
\text { use of scents for the environment } \\
\text { and reflexology (auricular therapy). }\end{array}$ & $\begin{array}{l}\text { Exercising asking for help and } \\
\text { taking a day off. }\end{array}$ \\
\hline WEEK 5 MEETING & $\begin{array}{l}\text { Welcoming of caregivers. Answer } \\
\text { the question: "How do I take care } \\
\text { of myself?". }\end{array}$ & $\begin{array}{l}\text { Art therapy using games and music, } \\
\text { using scents for the environment. }\end{array}$ & $\begin{array}{l}\text { Reflect on wishes for the present } \\
\text { time and plans for the future. }\end{array}$ \\
\hline WEEK 6 MEETING & $\begin{array}{l}\text { Welcoming of caregivers. Answer } \\
\text { the question: "How do I prepare } \\
\text { to take care of someone?". }\end{array}$ & $\begin{array}{l}\text { For the scenario, stretchers, mats, } \\
\text { pillows, wheelchair. Printed material. }\end{array}$ & $\begin{array}{l}\text { Exercise by stretching before, } \\
\text { during and at the end of the day. }\end{array}$ \\
\hline WEEK 7 MEETING & $\begin{array}{l}\text { Welcoming of caregivers and } \\
\text { opening the "Garden of Care". }\end{array}$ & $\begin{array}{l}\text { Mats and mirrors. Massage therapy, } \\
\text { meditation, use of scents for the } \\
\text { environment, reflexology (auricular } \\
\text { therapy) and art therapy from } \\
\text { gardening. }\end{array}$ & $\begin{array}{l}\text { Strengthen the care network by } \\
\text { asking for help and counting on } \\
\text { the help of family members, the } \\
\text { group and the Health Unit team. }\end{array}$ \\
\hline
\end{tabular}

Source: Created by the authors. 
tried during the week until the subsequent meeting included exercises, self-massage and herbal teas as suggestions.

In the second meeting, caregivers worked on how to deal with daily stress. They were asked if they had any daily activities where they felt more overwhelmed and what they usually did to feel well. The proposal of the meeting was to work with art therapy using gardening as a therapeutic resource to deal with stress. Plant seedlings were brought in and each participant made themselves available to cultivate them. Expanding the look at the physical space of the health unit, caregivers decided to transform a flowerbed between the medical offices that was a dead space and had no function, at each meeting and collectively, into a garden. From this meeting onwards, all the meetings began with the participants listening to how the previous meeting had resonated and the activity suggested for the week.

The third meeting was the moment to get to know the family and the caregivers' social network, based on the construction of the Genogram and the Ecomap. These instruments are used in the family approach as efficient ways of collecting information: from the genogram it is possible to obtain data on the family constitution - structure, composition, patterns, relationships, allowing, with their analysis, to establish a perception of the psychosocial situation of the user and family members ${ }^{24}$. The ecomap signals the systems that surround and connect with the person, the family and the community ${ }^{25}$. Knowing how to use these tools is essential in medical education, as they contribute to a systemic approach to the individual. With these resources, it was possible for caregivers to discover with who and where to seek help and realize that they were not alone. The suggested activity to be carried out at home was allowing oneself to ask for and accept help to care for the other.

In the fourth meeting with the group, the caregiver's rights were discussed, emphasizing that individuals who take care of themselves have better emotional and physical conditions to take care of other people ${ }^{26}$. The difficulty of one of the members in organizing the medications of the person cared by them was also resolved with the group. The students organized containers marked with pictures (morning = sun; afternoon = lunch plate; night $=$ moon and stars), and each pack of pills was marked with different colors and distributed in the container corresponding to the time of use. Information on medication times was recorded on an A4 sheet, and the caregiver was instructed to fix the sheet to a visible place, which could be consulted, when necessary, by anyone helping with care.

For the fifth meeting, we invited a psychologist to talk about self-care. Triggering questions were written on paper, such as: "what do you do to take care of yourself?"; "How do you see yourself in five years?"; "What is your biggest dream?" and placed in a small box that was passed from hand to hand between the participants in a "hot potato" type game. To complete the activity, the embracement was carried out with a round of hugs.

In the sixth meeting, we invited the NASF physical therapist to talk with caregivers about how to deal with everyday situations that cause pain in the body, how to bathe and move the person in bed. Stretching exercises were recommended and then, using stretchers, mats, pillows and a wheelchair, they were taught how to accommodate the cared person in bed, changes in position, how to stay seated, transport from bed to chair and aid for walking. Finally, printed material with the guidelines was handed to each caregiver.

In the seventh meeting, the closure of the group was organized. Mattresses and chairs were placed in one of the rooms and the caregivers were instructed (if they wanted to) to lie down or sit down to receive some care, including massage therapy, aromatherapy and auricular therapy. Small mirrors were distributed so that everyone could look at themselves and recognize the person who was learning to take care of themselves. Then, each person was given the certificate of "Best Caregiver in the World". After this moment, all the participants were invited to inaugurate the "Garden of Care", a result of the individual and collective transformation of the participants of the therapeutic group that overflowed "the care" to the physical space of the Health Unit.

\section{DISCUSSION}

Each of the reported meetings allowed reflections, changes in habits and the training of skills. In the first one, the participants were able to perceive that they were not alone in relation to the complaints: the suffering of one was found in the other. In the group, what they perceived as different was the time each person performed the role of caregiver and the degree of autonomy of the person receiving the care. A study with fourteen caregivers of elderly people monitored at a UBS in the city of Porto Alegre, state of Rio Grande do Sul, Brazil, concluded that the greater the person's degree of dependence on the caregiver, the greater the caregiver's overload ${ }^{8}$. In this context, the prolonged time dedicated to caring for another person or the perspective of that time, together with the isolation picture in the management of demands, also contributed to increase the caregiver's suffering ${ }^{27}$.

In each of the activities, the students were able to exercise time management and perform the role of mediators in group coordination. Based on the caregivers' speeches, they realized the importance of being a listening space for each individual, fully understanding them, an essential attitude for establishing the doctor-patient link and relationship. They were also able to deconstruct the image of the doctor as a 
prescriber, experiencing the taking care of the other through light technologies, such as reading a children's book.

It was interesting to see that each caregiver was organizing themselves so that they could be present at the meetings, as they felt welcomed and identified the benefits of the self-care moments, even if they only experienced them for a few minutes in a day. Equally significant was observing the self-recognition of the students and professionals of the team as caregivers who were allowing themselves to experience each self-care activity proposed for the group. Caring fulltime for people only makes sense if the caregiver takes care of themselves: it is only possible to look at the suffering of the other if the person is taking care of their own suffering ${ }^{28}$.

The space was also important to discuss with the students basic concepts such as Functional Literacy in Health, which consists in the understanding, interpretation and application of information about health, for preventive actions, based on the understanding that people with a satisfactory level of literacy can take care of themselves better than those with a limited level ${ }^{29}$. This fact reveals the importance of health professionals to be concerned with the cognition of the assisted individuals, evaluating the need for adjustments to ensure assimilation of the guidelines.

The impacts of the meeting with the physical therapist were seen in the home visits. In some households, the printed material was attached very close to the bed of the person being assisted, and it was consulted mainly for the stretching of those who were bedridden. Greater dexterity for moving the bedridden person was observed. A study carried out with twenty informal caregivers of people with disorders resulting from stroke or spinal cord trauma followed at a clinic in the state of Paraná showed that giving physical therapeutic guidance to caregivers, despite not showing any significant difference in relation to overload or general increase in quality of life, significantly affects the reduction of pain and improvement in the mental health of caregivers ${ }^{30}$.

At the end of the group activities, it was possible to see that the participants were more open to receiving care. The contact with some PICS allowed improving the perception of the impacts of stress on the body in the form of pain and tension and, when applied together with conventional Medicine, it allowed a less invasive approach, providing an understanding of the illness. When they assimilated that to take care of the other one must take care of oneself, the offer of care became easier. And the garden blossomed and was inaugurated.

The other garden of this work was the students' learning about their own self-care and the possibilities of intervention in a community. When carrying out the therapeutic group, they allowed themselves to know, experience and apply the PICS, as well as monitor the results based on the caregivers' reports. They were also able to experience the establishment of the doctor-patient relationship based on bonding and the prescription of other types of care based on person-centered listening, contributing to the non-medicalization of problems such as human suffering. They learned the importance of teamwork, coordinating the group and managing their time, in addition to understanding the meaning of equity, integrality and longitudinality in the practice of FCM and they thrived.

\section{CONCLUSION}

Caring is a practice of respect and compassion, a movement of giving and taking, asking and accepting. The reduction of stress, overload and isolation of caregivers of people followed during home visits was possible through the use of light technologies worked on in a therapeutic group. The identification and improvement of the support network was a fundamental process for the autonomy of caregivers in promoting assistance, as well as the recognition of self-care as a continuous process under the responsibility of the caregiver and the health team.

It was observed that the group existed outside the health unit, in meetings at the end of the afternoon or during the week to share the pleasure of living. Despite this, and perhaps because of the group structuring on a weekly basis, some participants found it difficult to be present at the meetings. Some because the person being cared for had to be hospitalized, or because they could not find someone to take care of the person at the time scheduled for the meeting. A longer time interval between meetings can improve attendance for participants.

The importance of this report was to realize the contribution of an intervention in the community also for the training of the two students attending the Internship period of the medical course. It was important to demonstrate that, in order to take care of people, it is necessary to teach and learn to listen, respect the knowledge and choices of others and that these practices are possible in the extremely complex scenario of the PHC, the FHS and the FCM rotation. Additionally, these are experiences that can be reproduced in other health units, addressing other topics, significantly contributing to the education of students, the lives of professionals and users who visit the services.

\section{AUTHORS' CONTRIBUTION}

Ana Vitória Teixeira de Medeiros Gomes and Erika Denise de Vasconcelos Florentino contributed to the structuring and coordination of the intervention project at the $\mathrm{BHU}$, participating in the planning, scientific construction, performance, writing and final version of the manuscript. Myrlla Soares de Oliveira, Thaiany Rego Silva and Jucimara Alves de Souza contributed to 
the structuring and coordination of the intervention project at the BHS and to the final review of the manuscript.

\section{CONFLICTS OF INTEREST}

The authors declare no conflicts of interest.

\section{SOURCES OF FUNDING}

The authors declare no sources of funding.

\section{REFERENCES}

1. Boff L. Saber cuidar: ética do humano - compaixão pela terra. 20a ed. Petrópolis: Vozes; 2014.

2. Brandão FSR, Costa BGS, Cavalcanti ZR, Bezerra MR, Alencar LCA, Leal MCC. Sobrecarga dos cuidadores idosos assistidos por um serviço de atenção domiciliar. Rev Enferm UFPE On Line. 2017;11(supl 1):S272-9. doi: 10.5205/ reuol.7995-69931-4-SM.1101sup201704.

3. Baptista BO, Beuter M, Girardon-Perlini NMO, Brondani CM, Budó MLD, Santos NO. A sobrecarga do familiar cuidador no âmbito domiciliar: uma revisão integrativa da literatura. Rev Gaucha Enferm. 2012;33(1):147-56. doi: 10.1590/S1983-14472012000100020.

4. Ahnerth NMS, Dourado DM, Gonzaga NM, Rolim JA, Batista EC. "A gente fica doente também": percepção do cuidador familiar sobre o seu adoecimento. Gerais: Rev Interinst Psicol. 2020;13(1):1-20. doi: 10.36298/ gerais2020130106.

5. Jesus ITM, Orlandi AAS, Zazzetta MS. Sobrecarga, perfil e cuidado: cuidadores de idosos em vulnerabilidade social. Rev Bras Geriatr Gerontol. 2018;21(2):199-209. doi: 10.1590/1981-22562018021.170155.

6. Mahmud SJ, Mano MAM, Lopes JMC, Savassi LCM. Abordagem comunitária: cuidado domiciliar. In: Gusso G, Lopes JMC, Dias LC, organizadores. Tratado de medicina e comunidade: princípios, formação e prática. 2a ed. Porto Alegre: Artmed; 2019. v. 1, p. 313-24.

7. Rezende G, Gomes CA, Rugno FC, Carvalho RC, De Carlo MMRP. Sobrecarga de cuidadores de pessoas em cuidados paliativos: revisão integrativa da literatura. Medicina (Ribeirão Preto). 2016;49(4):344-54. doi: 10.11606/ issn.2176-7262.v49i4p344-354.

8. Lopes CC, Oliveira GA, Stigger FS, Lemos AT. Associação entre a ocorrência de dor e sobrecarga em cuidadores principais e o nível de independência de idosos nas atividades de vida diária: estudo transversal. Cad Saude Colet. 2020;28(1):98-106. doi: 10.1590/1414-462X202028010184.

9. Drulla AG, Alexandre AMC, Rubel FI, Mazza VA. A visita domiciliar como ferramenta ao cuidado familiar. Cogit Enferm. 2009;14(4):667-74. doi: http://dx.doi.org/10.5380/ce.v14i4.16380.

10. Rezende TCB, Coimbra AMV, Costallat LTL, Coimbra IB. Factors of high impacts on the life of caregivers of disabled elderly. Arch Gerontol Geriatr. 2010;51(1):76-80. doi: 10.1016/j.archger.2009.08.003.

11. Lino VTS, Rodrigues NCP, Camacho LAB, O'Dwyer G, Lima IS, Andrade MKN, et al. Prevalência de sobrecarga e respectivos fatores associados em cuidadores de idosos dependentes, em uma região pobre do Rio de Janeiro, Brasil. Cad Saude Publica. 2016;32(6):e00060115. doi: 10.1590/0102-311X00060115.

12. Faria $A A, A$ parecido $A M, C r u z ~ G L$, Khater $E$. Cuidando de quem cuida - o papel do psicólogo com cuidadores de pacientes paliativos. Saúde Foco. 2017];1(9):25-36 [acesso em 2 set 2020]. Disponível em: https://portal. unisepe.com.br/unifia/wpcontent/uploads/sites/10001/2018/06/004_ artigo_saude_template.pdf.

13. Merhy EE. A perda da dimensão cuidadora na produção da saúde - uma discussão do modelo assistencial e da intervenção no seu modo de trabalhar a assistência. In: Reis AT, Santos AF, Campos CR, Malta DC, Merhy EE, editores. Sistema Único de Saúde em Belo Horizonte: reescrevendo o público. São Paulo: Xamã; 1998. p. 103-20 [acesso em 2 de set. 2020]. Disponível em: https:// www.researchgate.net/publication/33023409_A_perda_da_dimensao_ cuidadora_na_producao_da_saude_uma_discussao_do_modelo_ assistencial_e_da_intervencao_no_seu_modo_de_trabalhar_a_assistencia.
14. Casanova F, Osorio LC, Dias LC. Abordagem comunitária: grupos na atenção primária à saúde. In: Gusso G, Lopes JMC, Dias LC, organizadores. Tratado de medicina e comunidade: princípios, formação e prática. 2a ed. Porto Alegre: Artmed; 2019. v. 1, p. 325-33.

15. Santos RL, Sousa MFB, Brasil D, Dourado M. Intervenções de grupo para sobrecarga de cuidadores de pacientes com demência: uma revisão sistemática. Rev Psiquiatr Clín. 2011;38(4): 161-7. doi: 10.1590/S010160832011000400009

16. Oliveira KS, Baduy RS, Melchior R. O encontro entre Núcleo de Apoio à Saúde da Família e as equipes de Saúde da Família: a produção de um coletivo cuidador. Physis. 2019;29(4):e290403. doi: 10.1590/s010373312019290403.

17. Brasil. Portaria no 849, de 27 de março de 2017. Inclui a arteterapia, ayurveda, biodança, dança circular, meditação, musicoterapia, naturopatia, osteopatia, quiropraxia, reflexoterapia, reiki, shantala, terapia comunitária integrativa e yoga à Política Nacional de Práticas Integrativas e Complementares. Diário Oficial da União; 28 mar 2017.

18. Barreto AF. Práticas Integrativas e Complementares como ética da sensibilidade no cuidado humano. J Manag Prim Heal Care. 2017;8(2):181202. doi: https://doi.org/10.14295/jmphc.v8i2.525.

19. Yaari M, Roman AC. Práticas integrativas. In: Gusso G, Lopes JMC, Dias LC, organizadores. Tratado de medicina e comunidade: princípios, formação e prática. 2a ed. Porto Alegre: Artmed; 2019. v. 1, p. 786-97.

20. Universidade Federal do Vale do São Francisco. Colegiado Acadêmico de Medicina - Petrolina/PE. Regimento do internato médico. 2019 [acesso em 12 set 2020]. Disponível em: http://www.medicina.univasf.edu.br/ arquivos/Regimento\%20do\%20Internato\%20Medico.pdf.

21. Romanholi RMZ, Cyrino EG. A visita domiciliar na formação de médicos: da concepção ao desafio do fazer. Interface Comun Saúde Educ. 2012;16(42):693-705. doi: 10.1590/S1414-32832012000300009.

22. Lopes WO, Saupe R, Massaroli A. Visita domiciliar: tecnologia para o cuidado, o ensino e a pesquisa. Cienc Cuid Saúde. 2008;7(2):241-7. doi: 10.4025/cienccuidsaude.v7i2.5012

23. Osório LC. Grupoterapias: abordagens atuais. Porto Alegre: Artmed; 2007

24. Muniz JR, Eisenstein E. Genograma: informações sobre família na (in) formação médica. Rev Bras Educ Med. 2009;33(1):72-9. doi: https://doi. org/10.1590/S0100-55022009000100010.

25. Dias LC. Abordagem familiar. In: Gusso G, Lopes JMC, Dias LC organizadores. Tratado de medicina e comunidade: princípios, formação e prática. 2a ed. Porto Alegre: Artmed; 2019. v. 1, p. 282-92.

26. Born T, organizadora. Cuidar melhor e evitar a violência: manual do cuidador da pessoa idosa Brasília: Secretaria Especial dos Direitos Humanos, Subsecretaria de Promoção e Defesa dos Direitos Humanos; 2008 [acesso em 3 set 2020]. Disponível em: https://bibliotecadigital.mdh.gov.br/ jspui/handle/192/456\#: :text=O\%20manualser\%C3\%A1\%20um\%20 instrumento\%20que,lhe\%20um\%20envelhecer\%20com\%20dignidade.

27. Fernandes MGM, Garcia TR. Determinantes da tensão do cuidador familiar de idosos dependentes. Rev Bras Enferm. 2009;62(1):57-63. doi: http:// dx.doi.org/10.1590/S0034-71672009000100009.

28. Arantes ACQ. A morte é um dia que vale a pena viver. Rio de Janeiro: Casa da Palavra; 2016.

29. Passamai MPB, Sampaio HAC, Dias AMI, Cabral LA. Letramento funcional em saúde: reflexões e conceitos sobre seu impacto na interação entre usuários, profissionais e sistema de saúde. Interface Comun Saúde Educ. 2012;16:301-14 [acesso em 12 set 2020]. Disponível em: scielo. $\mathrm{br} / \mathrm{pdf} / \mathrm{icse} / 2012 \mathrm{nahead} / \mathrm{aop} 2812 \#:$ :text=Functional\%20health\%20 literacy.,de\%20decisões\%20adequadas\%20em\%20saúde.

30. Fernandes BCW, Ferreira KCP, Marodin MF, Val MON, Fréz AR. Influência das orientações fisioterapêuticas na qualidade de vida e na sobrecarga de cuidadores. Fisioter Mov. 2013;26(1): 151-8. doi: http://dx.doi. org/10.1590/S0103-51502013000100017. 